\title{
Exploitation of Plant Growth Substances for Improving the Yield and Quality of Pomegranate under Ultra High Density Planting
}

\author{
T. Shanmugasundaram ${ }^{1 *}$ and G. Balakrishnamurthy ${ }^{2}$ \\ ${ }^{1}$ Department of Vegetable Crops, HC and RI, TNAU, Coimbatore - 641003, Tamil Nadu, India \\ ${ }^{2}$ Department of Fruit Crops, HC and RI, TNAU, Coimbatore - 641003, Tamil Nadu, India \\ *Corresponding author
}

\section{A B S T R A C T}

\begin{tabular}{|l|}
\hline Ke y w o r d s \\
Pomegranate, \\
Mridula, Growth \\
substances, Yield, \\
Aril, Anthocyanin.
\end{tabular}

\section{Introduction}

Pomegranate (Punica granatum L.) belongs to the family Punicaceae. It is a shrub or small tree attaining a height of $4-10 \mathrm{~m}$. There are three main seasons of flowering known as Ambe bahar, Mrig bahar and Hasta bahar. Flowers appear as singles or in small clusters, generally of 2-6 flowers occasionally at the
The present investigation was conducted in the Department of Fruit Crops, HC \& RI, TNAU, Coimbatore during the year 2011 to 2013 at Jain Irrigation Systems Pvt. Limited Farms, (JISL), Udumalpet, to investigate the response of plant growth substances on yield and quality of pomegranate cv. Mridula under ultra high density planting (UHDP). The experiments was laid out in randomized block design with nine treatment of plant growth substances viz., NAA $10 \mathrm{ppm}, \mathrm{GA}_{3} 50 \mathrm{ppm}$ and $\mathrm{KNO}_{3} 1 \%$ and combination of each two and three including of water spray and were sprayed three times from 150 days after pruning subsequently, at 30 and 60 days after first spray and absolute control were maintained. Three replications were followed to investigate various yield and quality attributes of three year old TC pomegranate (Punica granatum L.) cv. Mridula grown under UHDP. The results revealed that application of NAA $10 \mathrm{ppm}+\mathrm{GA}_{3} 50 \mathrm{ppm}$ was recorded the maximum number of fruits per plant (65.11), average fruit weight $(272.5 \mathrm{~g})$, Fruit volume $(290 \mathrm{cc})$, fruit length $(7.7 \mathrm{~cm})$, fruit diameter $(7.9 \mathrm{~cm})$, number of aril per fruit (670), total aril weight per fruit (186.2 g), 100 aril weight $(25.85 \mathrm{~g})$, aril recovery $(25.85 \%)$, total seed weight $(20.23 \mathrm{~g})$, fruit yield / plant $(17.74 \mathrm{~kg})$, as compared with water spray. In regards to the quality attributes application of $\left(\mathrm{GA}_{3} 50 \mathrm{ppm}+\mathrm{KNO}_{3} 1 \%\right)$ registered the highest values for total sugar $(9.01 \%)$, reducing sugar $(7.35 \%)$, total soluble solids (16.2\%) and anthocyanain (18.85\%) content as compared with water spray. Therefore application of three sprays of NAA $10 \mathrm{ppm}+\mathrm{GA}_{3} 50 \mathrm{ppm}$ starting from 150 days after pruning and subsequently at 30 days interval resulted in the highest yield attributing characters whereas, the quality of pomegranate was increased by application of $\mathrm{GA}_{3} 50 \mathrm{ppm}+\mathrm{KNO}_{3} 1 \%$. It could be considered as best combination for getting increased yield and quality for three years old TC pomegranate cv. Mridula. 
the fruit is a berry (Still, 2006), the fruit is a fleshy inferior berry, with a thick skin enclosing the edible parts, with cavities (locules) of 4-15, separated by membranous partitions (carpellar membranes). The interior is filled with many fleshy seeds prismatic in shape. The numerous seeds are each surrounded by juicy, sub acid pulp (arils) which is the edible part. There are 1200-1300 seeds in the large-sized fruit with less in the smaller fruit. The fruit size can differ from 6 $12 \mathrm{~cm}$ in diameter and has a hard, tough skin leaves are simple and opposite with entire margins and deciduous in nature.

Pomegranate is non climacteric fruit therefore harvesting period is important to control the quality of fruits. Farmers need to know a suitable time for harvesting of pomegranates. Hence, physicochemical properties of fruits on tree by counting days after flowering are investigated. The correlation of physicochemical properties and maturity index is considered to determining of the suitable time for harvesting of pomegranates.

Fruit rind colour is an attribute that determines consumers' behaviour, and it is accepted as one of the most important external quality parameters (Ercisli, 2007). One of the most important quality characteristics of pomegranate is the red pigmentation of seeds and juice. This red colour depends on anthocyanin concentration and on the chemical structure of the individual anthocyanin (Holcroft et al., 1998).The physico-chemical characterization of pomegranate samples is important because the physico-chemical composition is closely related to the quality and preservation of products. Pomegranate fruit is consumed directly as fresh arils as well as fresh juice (Al-Said et al., 2009).

Beneficial effect of various plant growth regulators have been reported on many fruit crops and proved beneficial for improving quality and yield. Mostly the plant growth substances have been used for various beneficial effects such as promoting root growth, number of flowers, increasing the fruit set, fruit size and quality for inducing early uniform fruit ripening. Although, the effect of foliar applied chemicals on yield and fruit quality have been studied by many workers the information of such effect on pomegranate fruit is very scanty. Hence, the present investigation was undertaken to study the response of plant growth regulators on flowering, yield and quality of pomegranate cv. mridula under ultra high density planting.

The plant growth regulators (PGRs) are the chemical substances, when applied in small amounts modify the growth of plants either by stimulating or inhibiting part of the natural growth regulatory system. They play an important role in enhancing the source sink relationship and stimulate the translocation of photo assimilates to sink organs. From late 1980 onwards, uses of plant growth regulators have assumed significance in increasing the yield of horticultural crops by overcoming the physiological constraints (Prabakaran, 2002). Plant hormones play a vital role in improving female flower production and fruit set in a number of crops, thereby ensuring their full productive potential (Taiz and Zeiger, 2002). In accordance with this contention, the present study was conducted to understand the influence of certain plant growth regulating chemicals in improving the yield and quality potential of pomegranate, besides overcoming the physiological constraints.

\section{Materials and Methods}

The experimental field was located at JISL Farms, Elayamuthur, Udumalpet, Thirupur District which is about $90 \mathrm{~km}$ away from Coimbatore. The present experiment was carried out in three years old tissue cultured 
pomegranate plants of $\mathrm{cv}$. Mridula during the year 2011 to 2013. The spacing adopted was $3 \times 2 \mathrm{~m}$, with a plant population of 1667 plants $\mathrm{ha}^{-1}$. The experiment was laid out with five levels of NPK in randomized block design (RBD) and replicated three times. In this study Ambe bahar (January-February) flowering season was used and observation registered.

The above growth regulators were sprayed initially at 150 days after pruning (flowering to fruit set stage). Subsequently two sprays were given at 180 and 210 days after pruning (fruit development stage). The observations were taken from five uniform and randomly selected plants for each treatment. The observations namely, number of fruits per plant, average fruit weight, fruit volume, fruit length, fruit diameter, number of aril per fruit, total aril weight per fruit, 100 aril weight, aril recovery, total seed weight, fruit yield / plant, total sugar, reducing sugar, total soluble solids and anthocyanain content were recorded five representative plants.

\section{Methodology}

Total number of fruits per plant: The fruits borne on the plant were tagged individually, counted at the time of harvest and expressed in number.

Average fruit weight: Twenty fully matured fruits from each of the treatment combinations were randomly selected at field level and each fruit was weighed on electronic balance and average weight of the fruit per treatment was computed in gram $(\mathrm{g})$.

Fruit volume: The fruit volume was calculated by water displacement method in twenty fruits and the average was expressed in cubic centimetre (cc).

L/S of fruit length: The measurement of fruit length was made on the polar axis, that is between the apex and end of the stem along the curve by using thread and expressed in centimetre $(\mathrm{cm})$.

Fruit diameter: The fruit diameter was measured at the mid length of the fruit using thread and expressed in centimetre $(\mathrm{cm})$.

\section{Aril recovery}

The percentage of aril recovery was estimated and expressed in per cent (\%)

Percentage of aril recovery $=$

Average aril weight of fruit $\mathrm{x} 100$ Mean fruit weight

\section{Fruit quality analysis}

Total Soluble Solids (TSS): The total soluble solid of the fruit juice was determined by using hand refractometer (Erma. Tokyo - $\mathrm{A}^{\mathrm{O}}$ 32 ) and the results were expressed in ${ }^{\circ}$ Brix.

Total sugars: The total sugars content was estimated by using the method suggested by Hedge and Hofreiter (1962) and expressed in per cent.

Reducing sugars: The reducing sugars content was estimated by following the method suggested by Somogyi (1952) and expressed in per cent.

Anthocyanin content: The anthocyanin content of aril was estimated as per the method of Swain and Hillis (1959) and expressed in $\mathrm{mg} 100 \mathrm{~g}^{-1}$.

Yield per plant: Yield per plant was arrived at by harvesting the total number of fruits produced from selected plants individually and expressed in kilogram $(\mathrm{kg})$. 


\section{Results and Discussion}

\section{Effect of plant growth regulators on yield and yield contributing characters}

Yield depends on environmental (E), genetic (G) factors and strong $\mathrm{G} * \mathrm{E}$ interactions (Chapman, 2008). In the present study, the economic yield attributing characters viz., number of fruits per plant, average fruit weight, fruit volume, fruit length, fruit diameter, number of aril per fruit, total aril weight per fruit, 100 aril weight, aril recovery, total seed weight and fruit yield / plant was significantly increased by spraying of plant growth substances. Among the different treatments tried, sprayed with combination of NAA $10 \mathrm{ppm}+\mathrm{GA}_{3} 50 \mathrm{ppm}$ produced the highest number of fruits (65.11), average fruit weight $(272.5 \mathrm{~g})$, fruit volume $(290 \mathrm{cc})$, fruit length $(7.7 \mathrm{~cm})$, fruit diameter $(7.9 \mathrm{~cm})$, number of aril per fruit (670), total aril weight per fruit (186.2 g), 100 aril weight (25.85 g), aril recovery (25.85\%), total seed weight $(20.23 \mathrm{~g})$ and fruit yield / plant $(17.74 \mathrm{~kg})$ followed by combination of NAA $10 \mathrm{ppm}+\mathrm{GA}_{3} 50 \mathrm{ppm}+1 \% \quad \mathrm{KNO}_{3}$ (Table 1).

The lowest yield parameters were recorded by control $\left(T_{1}\right)$ water spray. This might be due to production of highest number of hermaphrodite flowers per plant and might be due to reduced fruit drop and higher fruit retention. On the other hand (Reddy et al., 2012) reported that in pomegranate cv. Ganesh the maximum numbers of fruits (63.17) were obtained when NAA alone was applied at $40 \mathrm{ppm}$ followed by $\mathrm{GA}_{3}$ at lower concentration i.e. $25 \mathrm{ppm}$ produced 52.33 numbers of fruits. Exogenous application of gibberellic acid appears to favour various growth parameters resulting in production of robust plant that can produce and support a large number of inflorescences. As gibberellic acid plays a major role in regulating assimilation and supply to developing sink (Taiz and Zieger, 2002), this treatment favoured the production of maximum number of fruits. A significant increase in fruit length and fruit diameter obtained may be attributed due to nature of auxins (NAA) to stimulate cell division, cell elongation and membrane permeability to water uptake (Chaudhary et al., 2006). Gibberellins are involved in cell division and cell elongation. They are known to influence fruit size (Zhang et al., 2011).

Gibberellic acid is also reported to promote growth by increasing plasticity of the cell wall followed by the hydrolysis of starch into sugars which reduces the cell water potential, resulting in the entry of water into the cell and causing elongation (Richard, 2006). With respect to fruit weight of pomegranate (Reddy et al., 2012) and (Ghosh et al., 2009) obtained higher fruit weight in the cv. Ganesh and in the cv. Ruby by the application of $\mathrm{GA}_{3} 75$ ppm and $\mathrm{GA}_{3} 10 \mathrm{ppm}$.

The results of the present study revealed that the plants sprayed with NAA $10 \mathrm{ppm}+\mathrm{GA}_{3}$ $50 \mathrm{ppm}$ produced the maximum fruit weight (272.5g) followed by combination of NAA 10 $\mathrm{ppm}+\mathrm{GA}_{3} 50 \mathrm{ppm}+1 \% \mathrm{KNO}_{3}$. Beneficial role of NAA and $\mathrm{GA}_{3}$ in improving fruit weight was also reported by (Pawar et al., 2005) in Pomegranate. Positive role of auxins like NAA along with $\mathrm{GA}_{3}$ application on fruit weight could be explained from the fact that these are associated with cell division and cell enlargement accompanied by increased supply of photosynthates to the developing berries. Weaver, 1972 and Ghosh et al., 2009 reported that NAA $10 \mathrm{ppm}$ recorded a maximum fruit weight of $29.4 \mathrm{~g}$ in Aonla. At higher concentration, the weight of the fruit was reduced. Source, strength and activity and translocation efficiency are the major contributors for better fruit filling, provided the soil moisture and growing environment are not adverse. 
Table.1 Effect of plant growth substances on number of fruits per plant, average fruit weight (g), fruit volume (cc), fruit length (cm), fruit diameter $(\mathrm{cm})$, number of arils per fruit, total aril weight $(\mathrm{g}), 100$ aril weight $(\mathrm{g})$, aril recovery $(\%)$, total seed weight (g) and yield per plant $(\mathrm{kg})$ of Pomegranate cv. Mridula under UHDP

\begin{tabular}{|c|c|c|c|c|c|c|c|c|c|c|c|}
\hline Treatment & $\begin{array}{c}\text { Number } \\
\text { of } \\
\text { fruits } \\
\text { per } \\
\text { plant }\end{array}$ & $\begin{array}{l}\text { Average } \\
\text { fruit } \\
\text { weight } \\
\text { (g) }\end{array}$ & $\begin{array}{c}\text { Fruit } \\
\text { volume } \\
\text { (cc) }\end{array}$ & $\begin{array}{r}\text { Fruit } \\
\text { length } \\
(\mathrm{cm})\end{array}$ & $\begin{array}{c}\text { Fruit } \\
\text { diameter } \\
\text { (cm) }\end{array}$ & $\begin{array}{c}\text { Number } \\
\text { of arils } \\
\text { per } \\
\text { fruit }\end{array}$ & $\begin{array}{c}\text { Total } \\
\text { aril } \\
\text { weight } \\
\text { (g) }\end{array}$ & $\begin{array}{c}100 \\
\text { aril } \\
\text { weight } \\
\text { (g) }\end{array}$ & $\begin{array}{c}\text { Aril } \\
\text { recovery } \\
(\%)\end{array}$ & $\begin{array}{c}\text { Total } \\
\text { seed } \\
\text { weight } \\
\text { (g) }\end{array}$ & $\begin{array}{c}\text { Yield } \\
\text { per } \\
\text { plant } \\
(\mathbf{k g})\end{array}$ \\
\hline $\mathbf{T}_{\mathbf{0}}$ & 47.89 & 235.2 & 225 & 6.5 & 7.3 & 628 & 145.9 & 22.29 & 62.0 & 12.76 & 11.26 \\
\hline $\mathbf{T}_{1}$ & 40.22 & 224.2 & 240 & 6.4 & 6.6 & 592 & 128.4 & 21.65 & 57.3 & 11.86 & 9.02 \\
\hline $\mathbf{T}_{2}$ & 58.33 & 249.4 & 265 & 6.9 & 7.1 & 645 & 151.4 & 24.48 & 60.7 & 12.35 & 14.55 \\
\hline $\mathbf{T}_{\mathbf{3}}$ & 50.56 & 251.6 & 270 & 7.0 & 7.2 & 650 & 154.7 & 24.90 & 61.5 & 13.61 & 12.72 \\
\hline $\mathbf{T}_{4}$ & 52.00 & 243.5 & 255 & 6.9 & 7.0 & 642 & 148.2 & 22.71 & 60.9 & 12.98 & 12.66 \\
\hline $\mathbf{T}_{5}$ & 65.11 & 272.5 & 290 & 7.7 & 7.9 & 670 & 186.2 & 25.85 & 68.3 & 20.23 & 17.74 \\
\hline $\mathbf{T}_{6}$ & 53.67 & 249.1 & 200 & 6.8 & 7.0 & 623 & 152.6 & 24.93 & 61.3 & 19.11 & 13.37 \\
\hline $\mathbf{T}_{7}$ & 50.67 & 250.6 & 205 & 6.8 & 7.1 & 631 & 160.1 & 23.20 & 63.9 & 19.03 & 12.70 \\
\hline $\mathbf{T}_{8}$ & 59.67 & 261.3 & 275 & 7.4 & 7.6 & 659 & 170.6 & 25.34 & 65.3 & 19.86 & 15.59 \\
\hline SEd & 1.113 & 6.086 & 6.214 & 0.104 & 0.168 & 13.873 & 3.042 & 0.533 & 1.410 & 0.363 & 0.275 \\
\hline CD (0.05) & 2.361 & 12.903 & 13.173 & 0.222 & 0.356 & 29.409 & 6.449 & 1.131 & 2.990 & 0.770 & 0.584 \\
\hline
\end{tabular}


Table.2 Effect of plant growth substances on total sugar (\%), reducing sugar (\%) total soluble solids ( ${ }^{\circ}$ Brix), and anthocyanin (mg $100 \mathrm{~g} \mathrm{-1}$ ) content of Pomegranate cv. Mridula under UHDP

\begin{tabular}{|c|c|c|c|c|}
\hline Treatment & $\begin{array}{c}\text { Total sugar } \\
(\mathbf{\%})\end{array}$ & $\begin{array}{c}\text { Reducing sugar } \\
(\mathbf{\%})\end{array}$ & $\begin{array}{c}\text { Total soluble solids } \\
\left({ }^{\mathbf{0}} \mathbf{B r i x}\right)\end{array}$ & $\begin{array}{c}\text { Anthocyanin } \\
\left(\mathbf{m g ~ 1 0 0 ~} \mathbf{~ g}^{-\mathbf{1}}\right)\end{array}$ \\
\hline $\mathbf{T}_{\mathbf{0}}$ & 8.90 & 7.30 & 16.0 & 16.3 \\
\hline $\mathbf{T}_{\mathbf{1}}$ & 8.46 & 7.14 & 15.5 & 15.49 \\
\hline $\mathbf{T}_{\mathbf{2}}$ & 8.58 & 7.27 & 15.0 & 16.45 \\
\hline $\mathbf{T}_{\mathbf{3}}$ & 8.75 & 7.30 & 15.2 & 16.79 \\
\hline $\mathbf{T}_{\mathbf{4}}$ & 8.29 & 7.24 & 16.0 & 18.04 \\
\hline $\mathbf{T}_{\mathbf{5}}$ & 8.86 & 7.21 & 15.6 & 16.58 \\
\hline $\mathbf{T}_{\mathbf{6}}$ & 8.40 & 7.25 & 15.8 & 17.74 \\
\hline $\mathbf{T}_{\mathbf{7}}$ & 9.01 & 7.35 & 16.2 & 18.85 \\
\hline $\mathbf{T}_{\mathbf{8}}$ & 8.95 & 7.26 & 15.8 & 18.13 \\
\hline $\mathbf{S E d}$ & $\mathbf{0 . 1 8 7}$ & $\mathbf{0 . 1 0 3}$ & $\mathbf{0 . 3 1 8}$ & $\mathbf{0 . 4 1 2}$ \\
\hline $\mathbf{C D}(\mathbf{0 . 0 5})$ & $\mathbf{0 . 3 9 6}$ & $\mathbf{0 . 2 2 0}$ & $\mathbf{0 . 6 7 4}$ & $\mathbf{0 . 8 7 5}$ \\
\hline
\end{tabular}

As observed in the present study, the yield per plant $(17.74 \mathrm{Kg}$ in three year old pomegranate plants under UHDP) was maximum in the treatment with the application of NAA 10 $\mathrm{ppm}+\mathrm{GA}_{3} 50 \mathrm{ppm}$. These results indicated that growth and physiological parameters were favorably influenced by these growth promoters with consequent increases in yield. Similar to the present findings, the influence of NAA and $\mathrm{GA}_{3}$ on increasing the yield of pomegranate cv. Ganesh was reported by Reddy et al., 2012 and they confirmed that increased number of fruits per plant might have contributed towards increase in yields due to growth regulators application.

\section{Effect of plant growth substances on quality parameters}

Pomegranate has been of recent interest for its nutritional, chemical, and antioxidant characteristics. The composition of mineral nutrients and chemical properties of fruit differs depending on cultivar, growing region, climate, maturity, and cultural practice (Mirdehghan and Rahemi, 2007). Minerals and plant growth hormones affect production and fruit quality either directly or indirectly. Most effects are indirect and act via alteration of vigor and capacity, and thereby the partitioning of primary and secondary photosynthetic metabolites such as carbohydrates, organic acids, proteins, growth regulators and flavor compounds (Khayyat $e t$ al., 2013).

Fruit quality is one of the important goals in any production system besides targeting for maximum fruit yield per unit area. In pomegranate, apart from average fruit weight, the quality is determined by total sugar, total soluble solids, anthocyanin and sugar acid ratio. As the pomegranate fruit matures on the plant, a reduction in the titrable acidity and parallel increase in TSS, pH, and colour intensity is observed (Kader, 2006).

The results of the present experiment on improving the quality of pomegranate fruits indicated that spraying thrice with $\mathrm{GA}_{3} 50$ $\mathrm{ppm}+\mathrm{KNO}_{3} 1 \%$ had recorded the maximum total sugar $(9.01 \%)$, reducing sugar $(7.35 \%)$, total soluble solids (16.2\%) and anthocyanain $(18.85 \%)$ content and the lowest was recorded in control $\left(\mathrm{T}_{1}\right)$ water spray. This could be explained from the light of findings of Ghosh et al., 2009 and Pandey, 1999 who reported that improvement in TSS of fruits due to auxins (NAA, 2, 4-D) and $\mathrm{GA}_{3}$ spray 
may be due to the fact that application of these growth regulators after fruit set probably improved the physiology of leaves, thereby causing better translocation of vital components in the fruit followed by assimilation and utilization of photosynthates by the developing fruit (Table 2).

Further, the sugar accumulation and TSS content depends on the photo assimilate production and its movements from the source leaves to sink.

The supplementary sprays of nutrients and plant growth regulator had stimulating effect on photo assimilate production and assimilate transport. The importance of plant growth regulators and nutrient spray treatments in improving the quality of berries was well established from the studies conducted elsewhere for total soluble solids (Warusavitharana et al., 2008).

From the above results it can be concluded that the application of three sprays with NAA $10 \mathrm{ppm}+\mathrm{GA}_{3} 50$ ppm starting from 150 days after pruning and subsequently at 30 days interval resulted in high yield and yield attributing characters whereas, the quality of pomegranate was increased by application of $\mathrm{GA}_{3} 50 \mathrm{ppm}+\mathrm{KNO}_{3} 1 \%$ in combination with 50 per cent recommended dose of fertilizers through fertigation (250:62.5:62.5 g NPK plant ${ }^{-1}$ year $^{-1}$ ).

Acknowledgement

The authors are thankful to Jain irrigation system Ltd, Elayamuthur, Udumalpet, Tirupur (Dt), Tamil Nadu and Dr. P. Soman, Shri. Shanthikumar Kataria, Senior VicePresidents, Dr. Sundarsingh, Senior agronomist, for providing critical suggestion and appropriate guidance's to carry out the experiment successfully during the period of research work.

\section{References}

Al-Said, F.A., Opara, L.U. and Al-Yahyali, R.A. 2009. Physico-chemical and textural quality attributes of pomegranate cultivars (Punica granatum L.) grown in the Sultanate of Oman J. Food eng., 90: 129-134.

Chapman, C. 2008. Use of crop models to understand genotype by environment interactions for drought in real-world and simulated plant breeding trials. Euphytica, 161(1-2): 195-208.

Chaudhary, B.R., Sharma, M.D., Shakya, S.M. and Gautam, D.M. 2006. Effect of plant growth regulators on growth, yield and quality of chilly (Capsicum annuum L.) at Rampur, Chitwan. J. Inst. Agric. Anim. Sci., 27: 65-68.

Ercisli, S., Orhan, E., Ozdemir, O., Sengul, M. 2007. The genotypic effects on the chemical composition and antioxidant activity of sea buckthorn (Hippophae rhamnoides L.) berries grown in Turkey. Scientia Horticulturae, 115(1):27-33.

Ghosh, S.N., Bera, B., Roy, S., Kundu, A. 2009. Effect of plant growth regulators on yield and fruit quality in Pomegranate cv. Ruby. J. Horti. Sci., 4(2): 158-160.

Hedge, J.E. and Hofreiter, B.T. 1962. In: Methods in Carbohydrate Chemistry Vol.17, (Eds.,) Whistler R.L. and BeMiller, J.N., Academic Press, New York, 420 PP.

Holcroft, D.M., Gil, M.I., Kader, A.A. 1998. Effect of carbon dioxide on anthocyanins, phenylalanine ammonia lyase and glucosyl transferase in the arils of stored pomegranates. J. Amer. Soc. Hort. Sci., 123(1): 136-140.

Kader, A.A. 2006. Postharvest biology and technology of Pomegranates. In: Seeram, N.P., Schulman, R.N., Heber, D. (Eds.), Pomegranates: ancient roots to modern 
medicine. CRC Press Taylor and Francis Group, Boca Raton, FL. PP 211-220.

Khayyat, M., Tehranifar, A., Zaree, M., Karimian, Z., Aminifard, M. H., Vazifeshenas, M. R., Amini, S., Noori, Y. and Shakeri, M. 2013. Effects of potassium nitrate spraying on fruit characteristics of 'Malas yazdi' Pomegranate. J. Plant Nutri., 35: $1387-$ 1393.

Mirdehghan, S.H. and Rahemi. M. 2007. Seasonal changes of mineral nutrients and phenolics in Pomegranate (Punica granatum L.) fruit. Scientia Horticulture, 111: 120-127.

Pandey, V. 1999. Effect of NAA and $\mathrm{GA}_{3}$ spray on fruit retention, growth, yield and quality of ber cv. Banarasi Karka. Orissa J. Horti., 27:69-73

Pawar, P.S., Jagtap, D.D., Garad, B.V., Shirsath, H.K., 2005. Effect of plant growth regulators on maturity, yield and fruit weight of Pomegranate cv. Mridula. Cur. Adv Plant Sci., 18:167170.

Prabakaran, G. 2002. Efficiency of bioregulators and nutrients on physiological efficiency and yield of black gram. M.Sc., (Ag). Thesis submitted to Tamil Nadu Agricultural University, Coimbatore.

Reddy, P., Prasad, D. 2012. Effect of plant growth regulators on fruit characters and yield of Pomegranate (Punica granatum L.) cv. Ganesh, Inter. J. Plant Animal and Envir. Sci., PP 91-93.

Richard, M. 2006. How to grow big peaches. Dep. of Hort.Virginia Tech. Blacksburg, VA 24061. Internet, www. Rce.rutgers.edu. 8 pages, August.

Somogyi, M. 1952. Notes on sugar estimation. J. Biol. Chem., 200: 245.

Swain, T. and W.E. Hillis. 1959. The phenolic constituents of Prunus domestica L. 1. The quantitative analysis of phenolic constituents. J. Sci. Food Agric., 10: 6368.

Taiz, L., Zeiger, E. 2002. Plant Physiol., Sinauer Associates Inc., Publishers sunderland, Massachusetts, USA.

Warusavitharana, A.J., Tambe, T.B. and Kshirsagar, D.B. 2008. Effect of cytokinins and brassinosteroid with gibberellic acid on yield and quality of Thompson seedless grapes. Acta Horti., 785: 217-224.

Weaver, R. Z. 1972. Biological effects and mechanism of action. In: Plant growth substances in agriculture, S. Chand and Company Ltd., Ram Nagar, New Delhi, PP. 90-117.

Zhang, C. and Whiting, M.D. 2011. Improving 'Bing'sweet cherry fruit quality with plant growth regulators. Scientia Horticulturae, 127: 341-346.

\section{How to cite this article:}

Shanmugasundaram, T. and Balakrishnamurthy, G. 2017. Exploitation of Plant Growth Substances for Improving the Yield and Quality of Pomegranate under Ultra High Density Planting. Int.J.Curr.Microbiol.App.Sci. 6(3): 102-109. doi: https://doi.org/10.20546/ijcmas.2017.603.011 